\title{
Arsenic in Drinking Water Toxicological Risk Assessment in the North Region of Burkina Faso
}

\author{
Jean Fidèle Nzihou ${ }^{1 *}$, Médard Bouda ${ }^{2}$, Salou Hamidou ${ }^{3}$, Jean Diarra ${ }^{4}$ \\ ${ }^{1}$ École Normale Supérieure/Université de Koudougou, Koudougou, Burkina Faso \\ ${ }^{2}$ Institut de Recherche en Mine et Environnement, Université de Québec en Abitibi-Témiscamingue, Rouyn-Noranda, Canada \\ ${ }^{3}$ Université Catholique de l'Afrique de l'Ouest (UCAO), Unité Universitaire à Bobo-Dioulasso, Bobo-Dioulasso, Burkina Faso \\ ${ }^{4}$ Institut de Génie de l'Environnement et du Développement Durable/Université de Ouagadougou, Ouagadougou, Burkina Faso \\ Email: jean_fidele@hotmail.com
}

Received February 4, 2013; revised March 6, 2013; accepted April 2, 2013

Copyright (C) 2013 Jean Fidèle Nzihou et al. This is an open access article distributed under the Creative Commons Attribution License, which permits unrestricted use, distribution, and reproduction in any medium, provided the original work is properly cited.

\begin{abstract}
Human health risks assessment were estimated by determining the nature and probability of adverse health effects in the North region's populations who are now exposed to arsenic from drinking water or will be exposed in the future. Several questions were addressed in this study: what types of health problems may be caused by arsenic from drinking water? What is the chance that people will experience health problems when exposed to different levels of arsenic? What arsenic level are people exposed to and for how long? To answers these questions we have first identified the hazard by evaluating arsenic concentration in thirty-four (34) bore-hole water points among the region based on the assumption of clinical cases related to drinking water. Arsenic concentration ranged from 0 up to 87.8 micrograms per liter. Next we assessed the dose-response of exposure to arsenic. Dose-response relationship describes how the likelihood and severity of adverse health effects are related to the amount and condition of exposure to arsenic. This required us to choose toxicity reference values (TRVs) above which adverse effects may occur for noncarcinogenic and for carcinogenic effects. Exposure factors have been calculated in two scenarios: people from 0 to 14 years old and people from 15 to 70 years. Exposure has been estimated indirectly through consideration of measured concentrations of arsenic in drinking water. This study show that people in the Yatenga, Zondoma and Passore provinces are at very high risk for developing several pathologies such as hyper pigmentation, keratosis, cancer, etc. due by chronic exposure to arsenic in drinking water.
\end{abstract}

Keywords: Arsenic Poisoning; Toxicity Reference Value; Risk Assessment; Carcinogenic Effect; Exposure Factor

\section{Introduction}

The North region, one of the thirteen (13) of Burkina Faso, has many economic and cultural potentialities. But it faces an acute lack of drinking water. Indeed, access to drinking water poses a major problem to the population both for its quality and its management. All water sources are exploited in order to meet the needs of drinking water. This region had respectively 51,595,875 and 6292 modern water access points but only 9,401,074 and 1129 of these were permanents respectively for years 2007, 2009 and 2011 [1]. It appears that for drilling and large diameter wells, with a population of $1,185,796$ inhabitants (2006 census), here is an average of 205 people by a modern water access point. Yet this estimation doesn't take in account the grown of the population. Apart from

${ }^{*}$ Corresponding author. this obvious problem of water scarcity in this region, there is also another due to remarkable pollution of groundwater. The rainfall is insufficient and erratic with annual precipitation of around 600 to $700 \mathrm{~mm}$. Banks dams are operated seasonally for market gardening activities and rivers are increasingly solicited by gold mining, mercury and cyanide are even used in the artisanal extraction of gold and this in the beds of rivers. There is a growing concern about the scale of anthropogenic pollution in this region.

In these fifteen (15) years, the appearance of clinical cases of hyperkeratosis, hyper pigmentation and necrotizing ulcerative tumor in some villages in the North region have attracted the attention of public authorities on the issue of diseases from water. Therefore the different structures of the ministries of water, health, environment and development partners (DANIDA, UNICEF, 
WHO) are highly involved in resolving this problem. The work reported in reference [2] has revealed the presence of arsenic in 159 tube-wells water at concentrations above the current standard of $50 \mu \mathrm{g} \cdot \mathrm{L}^{-1}$ in Burkina Faso. Groundwater contamination by arsenic levels is up to $1630 \mu \mathrm{g} \cdot \mathrm{L}^{-1}$ due to mining activities having been measured [3]. The analysis and epidemiological study reported in reference [4] has established a high correlation between the presence of Arsenic in patients' urines and the concentration of Arsenic in their source of drinking water in Yatenga, one of the four provinces of the North region. Solution to this problem was supposed to drill 100 new bore-hole in order to replace access point above national standards. But reference [1] indicates that only 55 new permanents water access points were created between 2009 and 2011. Maybe the situation has worsened in the meanwhile. After the newsworthy effect due to death caused by Arsenic contaminated water, Arsenic probably continues to silently endanger the health and kill people in the North region of Burkina Faso. The above facts raised the following questions:

- What are the levels populations' exposure to arsenic?

- From drinking water in the North region of Burkina Faso?

- What are the effects of arsenic on human health?

What health risk does undertake population when it is not possible to close an arsenic contaminated water access point?

The present study addresses these issues through a quantitative heal risk assessment based on data collected in the region. The study aims to predict in the medium and long run what health risk does encounter populations of this region exposed to arsenic in drinking water.

\section{Materials and Methods}

\subsection{Study Area}

The North Region is located in the northern part of Burkina Faso and extend between latitudes $12^{\circ} 38^{\prime}$ and $14^{\circ} 18^{\prime}$ North and longitude $1^{\circ} 33^{\prime}$ and $2^{\circ} 55^{\prime}$ West [5]. The region is bordered by the republic of Mali at the north and five other regions of Burkina Faso, namely: Sahel, Central North, Central Plateau, Central West and Mouhoun respectively at the north-east, east, south and west as depicted in Figure 1.

\subsection{Sampling}

Samples were collected from the four (4) provinces of the North region. Random sampling was used and no rule has been followed in relation to the space distribution of the sampled points. Thus, the number of samples per province does not depend on the size of the province, but the presumption of clinical cases. Samples were collected

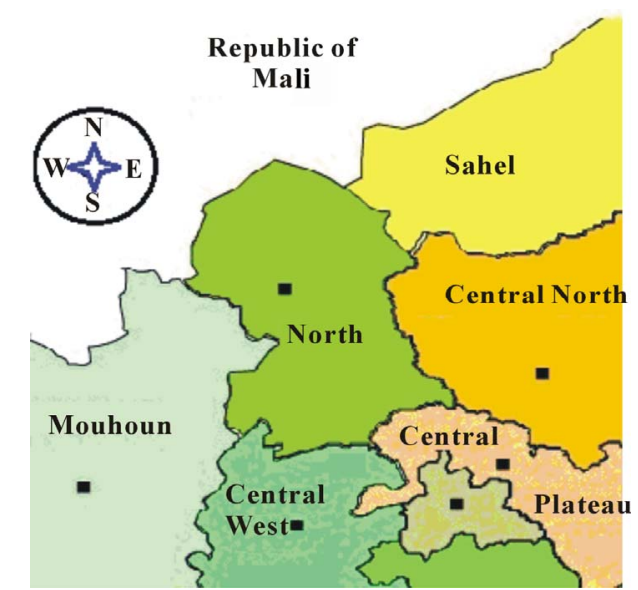

Figure 1. Delimitation of the North region.

from September 2006 to December 2006. The sampling period may seem short and old. But it was shown that "The arsenic content in water decreases with the productivity of drilling, but arsenic content in water content change from one site to another" [6]. Conclusion was also made that "it is the geological context which the source of arsenic level in groundwater". Besides "Arsenic contamination of groundwater has been found to occur due to geothermal influence to groundwater, mineral dissolution (e.g., pyrite oxidation), desorption in the oxidizing environment and reductive desorption and dissolution" $[7,8]$.

Several sampling points were selected based on the following criteria:

- Proximity to risk areas based on the assumption of clinical cases;

- Location and clear name (no ambiguity) of the sampling points;

- Easy access to the sampling points.

Each sample was labeled with the following information: the name of the operator, identification number of the sample, sampling point location, sampling date and nature (surface water or groundwater). Physical parameters such as, alkalinity, electrical conductivity (Eh), dissolved oxygen and temperature were measure din situ (during sampling) to avoid their alteration, even well preserved before arriving at the laboratory.

Laboratory analysis of the samples was done using:

- An automatic absorption spectrometer (AAS) graphite furnace for the determination of aluminum, cadmium, chromium, nickel and lead. Automatic dosing of the sample is done in the graphite AAS furnace. Thereafter there is a direct determination of the concentration of each element using a calibration curve, or from the specific absorbance of each element using the spectrometer is equipped with a background correction system continuously after performing a correction to the non-specific absorbance. 
- A FIAS (Flow Injection for Atomic Spectroscopy) system for the determination of arsenic, mercury and selenium. Before the analysis of mercury, the subset of sample is digested with nitric acid under the pressure of one bar. And, for the analysis of arsenic, the subset of sample is reduced with chlorine acid $(\mathrm{HCl})$, ascorbic acid and potassium iodine in an oven. The test sample is introduced into the feedback loop and automatically mixed with $\mathrm{HCl}$ and $\mathrm{NaBH}_{4}$. The reaction produces a volatile hydride that is transported into the quartz cell using a carrier gas as argon. In the cell hydride volatile is converted to gaseous metal atoms. The determination of the total concentration of calcium and magnesium and the total hardness is made by mole titration of calcium and magnesium ions with a solution of hydroxy naphtol and ethylenediamintetraacetic acid (EDTA) at $\mathrm{pH}$ 10. Black Tri chrome which gives a dark red or purple in the presence of calcium and magnesium ions, is used as an indicator.

The analysis in this study targeted a large number of parameters: temperature, $\mathrm{pH}$, conductivity, turbidity, the alkaline title, the fluoride ion, sulfates, phosphate, the sodium ions, potassium $(\mathrm{K})$, calcium $(\mathrm{Ca})$, magnesium $(\mathrm{Mg})$, etc. Temperature measured in situ showed no significant variation and was about $27^{\circ} \mathrm{C} \pm 1{ }^{\circ} \mathrm{C}$ and will not be reported in this paper.

\subsection{Toxicity Reference Values (TRVs)}

The effects studied are the deterministic and stochastic effects related to drinking water.

For deterministic effects: there are several TRVs for arsenic available in the literature. These are summarized in Table 1 below.

Table 1. Available TRVs for threshold effects.

\begin{tabular}{|c|c|c|c|c|}
\hline Source $^{a}$ & $\begin{array}{l}\text { Exposure } \\
\text { route }\end{array}$ & $\begin{array}{c}\text { Uncertainty } \\
\text { factor }\end{array}$ & Reference value $^{\mathrm{b}}$ & Revision year \\
\hline US EPA & Oral & 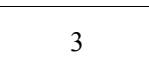 & $\begin{array}{c}\mathrm{RfD}=3 \times 10^{-4} \\
\mathrm{mg} / \mathrm{kg} / \mathrm{d}\end{array}$ & 1993 \\
\hline ATSDR & Oral (acute) & 10 & $\begin{array}{c}\mathrm{MRL}=5 \times 10^{-3} \\
\mathrm{mg} / \mathrm{kg} / \mathrm{d}\end{array}$ & 2000 \\
\hline ATSDR & Oral & 3 & $\begin{array}{c}M R L=3 \times 10^{-4} \\
\mathrm{mg} / \mathrm{kg} / \mathrm{d}\end{array}$ & 2005 \\
\hline RIVM & Oral & 2 & $\begin{array}{c}\mathrm{TDI}=10^{-3} \\
\mathrm{mg} / \mathrm{kg} / \mathrm{d}\end{array}$ & 2001 \\
\hline OEHHA & Oral & 3 & $\begin{array}{c}\mathrm{REL}=3 \times 10^{-4} \\
\mathrm{mg} / \mathrm{kg} / \mathrm{d}\end{array}$ & 2005 \\
\hline INERIS & Oral & 10 & $\begin{array}{c}\mathrm{VTR}=7 \times 10^{-5} \\
\mathrm{mg} / \mathrm{kg} / \mathrm{d}\end{array}$ & 2007 \\
\hline
\end{tabular}

${ }^{\mathrm{a}}$ US EPA = United States Environmental Protection Agency, ATSDR = Agency for Toxic Substances and Diseases Registry, RIVM = "RijskInstituutvoor Volksgezond heid en Milieu" (National Institute of Public Health and Environment in Netherands), OEHHA = Office of Environmental Health Hazard Assessment, INERIS = Institut National de l'Environnement Insustriel et des RISques. ${ }^{b} \mathrm{RfD}=$ Refernce Dose, $\mathrm{MRL}=$ Maximum Risk Level, TDI $=$ Tolerable Daily Intake, VTR $=$ Valeur Toxicologique de Référence (Toxicity Reference Value).
Among all these TRVs, we have taken the sixth, which is $7 \times 10^{-5} \mathrm{mg} \cdot \mathrm{kg}^{-1} \cdot \mathrm{d}^{-1}$. For selecting the TRV we used the study reported in reference [9]. TRV selection criteria from this study are:

- TRV obtained from the most recent study know to us.

- Study conducted over a long period of 6 months to 33 years for arsenic concentrations $<10 \mathrm{mg} \cdot \mathrm{L}^{-1}$ and $>229 \mathrm{mg} \cdot \mathrm{L}^{-1}$.

- The exposure route is oral.

- The study highlights the critical effects such as skin lesions (hyper pigmentation, hypo pigmentation, keratosis) which represent the main non-carcinogenic effects due to chronic oral exposure to arsenic.

- The method developed in this study is a multi-stages logistic regression to estimate odds ratios for skin lesions based on different levels of exposure to arsenic. Factors that may influence the multi-stages regression of more than $5 \%$ were included in the model (age, sex, education) and level of housing. They obtained a significant dose-response relationship between cumulative exposure or average arsenic and the risk of developing skin lesions has been demonstrated, the lowest category of exposure was used as control.

- The TRV is one of that best protects the population.

For stochastic effects: several TRVs were determined by various agencies including the US EPA, Health Canada and the OEHHA. Table 2 summarizes these values.

TRVs currently available are those related to skin cancer by the oral exposure. We should keep in mind that the carcinogenic effects of arsenic are also linked to bladder cancer and lung cancer [10].

We choose the value of the US EPA $\left(1.5 \mathrm{mg} \cdot \mathrm{kg}^{-1} \cdot \mathrm{d}^{-1}\right)$ which is the same as that proposed by OEHHA. Both are the most recent. This value was determined from the synthesis report made by US EPA in 1988. Studies used to establish the dose-response relation are those in references $[11,12]$. The critical effect retained is skin cancer. A multi-stages linear and quadratic model based on the prediction of apparition of cutaneous cancer according to dose and age was used.

\section{Results and Discussion}

Thirty-four (34) collected samples were analyzed. These samples (Table 3) are distributed as follow: 16 (55.88\%) in the Yatenga province, 09 in Passore $(26.47 \%), 5$ in Zondoma (11.76\%) and 4 in Loroum (11.76\%).

\subsection{Exposures Estimation}

\subsubsection{Determination of Emissions}

According to the 2006 census [13] the North region had $1,185,796$ inhabitants divided as follow: 553,164 in Yatenga, 323,222 in Passoré, 166,557 in Zondoma and 142,853 in Loroum. The population of the study area 
Table 2. Available VTRs for chronic oral exposure to arsenic for non-threshold effects.

\begin{tabular}{|c|c|c|c|c|}
\hline $\begin{array}{l}\text { Chemical } \\
\text { substance }\end{array}$ & Source & $\begin{array}{l}\text { Exposure } \\
\text { route }\end{array}$ & $\begin{array}{l}\text { Reference } \\
\text { value }^{\mathrm{a}}\end{array}$ & $\begin{array}{c}\text { Revision } \\
\text { year }\end{array}$ \\
\hline $\begin{array}{c}\text { Inorganic } \\
\text { Arsenic }\end{array}$ & US EPA & Oral & $\begin{array}{l}\mathrm{REL}=1.5 \\
(\mathrm{mg} / \mathrm{kg} / \mathrm{d})^{-1}\end{array}$ & 1998 \\
\hline $\begin{array}{c}\text { Inorganic } \\
\text { Arsenic }\end{array}$ & $\begin{array}{l}\text { Santé } \\
\text { Canada }\end{array}$ & Oral & $\begin{array}{l}\mathrm{TD}_{0.05}=1.8 \times \\
10^{-2} \mathrm{mg} / \mathrm{kg} / \mathrm{d}\end{array}$ & 2004 \\
\hline $\begin{array}{c}\text { Inorganic } \\
\text { Arsenic }\end{array}$ & OEHHA & Oral & $\begin{array}{c}\mathrm{REL}=1.5 \\
(\mathrm{mg} / \mathrm{kg} / \mathrm{d})^{-1}\end{array}$ & 2005 \\
\hline
\end{tabular}

${ }^{\mathrm{a}} \mathrm{REL}=$ Reference Exposure Level, $\mathrm{TD}_{0.05}=$ Tumoric Dose 0.05 .

Table 3. pH, K, Ca and As in collected samples values.

\begin{tabular}{|c|c|c|c|c|c|}
\hline Departement & Sampling place & pH & $\begin{array}{c}\mathbf{K} \\
(\mu \mathrm{g} / \mathrm{L})\end{array}$ & $\begin{array}{c}\text { Ca } \\
(\mu \mathrm{g} / \mathrm{L})\end{array}$ & $\begin{array}{c}\text { As } \\
(\mu \mathrm{g} / \mathrm{L}) \\
\end{array}$ \\
\hline \multirow{2}{*}{ Arbole } & Koeyiri & 7.1 & 4.1 & 25.65 & 1 \\
\hline & CSPS & 6.4 & 2.7 & 16.03 & 1 \\
\hline \multirow{2}{*}{ Bokin } & F. CSPS Sarma & 7.13 & 1.7 & 68.94 & 87.8 \\
\hline & F. Ecole Rana & 7.2 & 1.1 & 55.31 & 10.8 \\
\hline \multirow[t]{2}{*}{ Gourcy } & F. Yipala Koenba & 7.1 & 4.2 & 19.24 & 8.9 \\
\hline & Ramiga & 6.6 & 0.5 & 24.05 & 1 \\
\hline \multirow[t]{2}{*}{ Kalsaka } & Zingdegin & 7.5 & 0.7 & 17.64 & 1 \\
\hline & Bissighin-Saabin & 7.5 & 2.5 & 48.9 & 16.8 \\
\hline Kindibo & F. Silmi-mosse & 7.3 & 4.7 & 36.07 & 6.3 \\
\hline \multirow{2}{*}{ Kossouka } & Nabadogo & 7.2 & 3.7 & 28.06 & 5.8 \\
\hline & Deira & 7.2 & 0.9 & 63.33 & 1.1 \\
\hline \multirow{2}{*}{ Passoré } & Pougyango & 6.6 & 0.5 & 22.4 & 1.6 \\
\hline & Lemessere & 6.8 & 3.4 & 24.05 & 1.5 \\
\hline \multirow{5}{*}{ Rambo } & Ramgouma/Itaore & 7.35 & 5.5 & 42.48 & 5.6 \\
\hline & Nayiri & 7.3 & 1.7 & 50.5 & 9 \\
\hline & Ukoudin & 7 & 4.4 & 27.25 & 1 \\
\hline & Massogo-yiri & 7 & 1.8 & 39.28 & 1 \\
\hline & Tiibi-Zinczougou & 7 & 0.5 & 21.64 & 1 \\
\hline \multirow{4}{*}{ Seguenega } & Paramyiri & 6.85 & 5.8 & 56.11 & 1 \\
\hline & Secteur 2 Toghin & 7.55 & 0.5 & 52.91 & 1 \\
\hline & Tingandin & 6.5 & 2.5 & 19.24 & 1 \\
\hline & Tognayiri & 7.15 & 3.1 & 28.06 & 1 \\
\hline \multirow[t]{2}{*}{ Tangaye } & Bonsomnomogo & 7.5 & 0.5 & 51.3 & 1.2 \\
\hline & CSPS & 7.15 & 1.2 & 16.03 & 2.1 \\
\hline \multirow[t]{3}{*}{ Titao } & Ecole/Noogo & 7.35 & 8.2 & 89.79 & 1 \\
\hline & F. DPAHRH & 6.95 & 4.2 & 133 & 1 \\
\hline & F. CSPS Rikba & 6.95 & 4.5 & 23.25 & 8.5 \\
\hline \multirow[t]{3}{*}{ Touogo } & F. Bankpore Ranawa & 7.1 & 0.5 & 16.03 & 6.5 \\
\hline & F. Ecole Kelgaum & 7.5 & 1.3 & 16.03 & 15.1 \\
\hline & Forage de kouma & 7.6 & 1.5 & 32.06 & 7.4 \\
\hline \multirow[t]{2}{*}{ Yako } & Rosin & 7.2 & 0.5 & 57.72 & 9 \\
\hline & Itaore & 7.1 & 1.9 & 56.11 & 1.9 \\
\hline
\end{tabular}

subject to contamination by arsenic includes all residents (men, women, children older than 4 years), living and drinking water in the region. There are 975,673 individuals, divided by province as follow: Yatenga 455,143 in- habitants, Passoré 265,947 inhabitants, Zondoma 137,043 inhabitants and Loroum 117,539 inhabitants .

\subsubsection{Population Exposure}

The major exposure route to arsenic in these populations is bore-wells water and more specifically drinking water from boreholes. Exposure duration range from 6 months to 33 years. Exposure levels of populations to arsenic ranged from less than $10 \mu \mathrm{g} \cdot \mathrm{L}^{-1}$ to over $87 \mu \mathrm{g} \cdot \mathrm{L}^{-1}$. We consider an exposure duration of 33 years in our scenario.

\subsubsection{Calculation of the Exposures}

We are here in the context of an oral contamination. Exposure dose (ED) and exposure factor (EF) can be calculated with the following equations [14]:

$$
\mathrm{ED}=(\mathrm{C} \times \mathrm{IR} \times \mathrm{AF} \times \mathrm{EF}) / \mathrm{BW}
$$

The exposure factor express how often and how long a person may be contacting a toxicant in environment.

Exposure Factor $=\mathrm{ED} \times(\mathrm{F} / \mathrm{AT})$, that is:

$$
\mathrm{ED}=(\mathrm{C} \times \mathrm{IR} \times \mathrm{AF} \times \mathrm{F}) /(\mathrm{BW} \times \mathrm{AT})
$$

where:

$\mathrm{C}=$ arsenic concentration in water (milligram//liter)

$\mathrm{IR}=$ Intake rate $(\mathrm{kg} /$ day $)$

$\mathrm{AF}=$ Bioavailability factor (unitless)

$\mathrm{EF}=$ Exposure factor (unitless)

$\mathrm{BW}=$ Body weight (kilograms)

$\mathrm{F}=$ Frequency of exposure (days/year)

$\mathrm{Ed}=$ Exposure duration (years)

$\mathrm{AT}=$ Averaging time $(\mathrm{Ed} \times 365$ days/year $)$

Exposure factor have been calculated for non-cancer effects and carcinogenic effects.

\subsubsection{Non-Carcinogenic Effects}

Exposure factor to arsenic in drinking water was calculated according to two scenarios: the first for " 0 - 14 years" and the second " 15 - 70 years".

In cases of chronic arsenic poisoning, skin lesions predominate: hyperkeratosis of the palms and soles, dotted hyper pigmentation concomitant with small hypo pigmented areas. In cases of poisoning by drinking water, these cutaneous signs are the most sensitive effects of arsenic on humans. Keratoses appear to be the earliest signs of arsenic poisoning.

Exposure doses calculated in Tables $\mathbf{4}$ and $\mathbf{5}$ are far higher than that of the maximum daily intake in Yatenga, Passoré and Zondoma provinces. This is illustrated by clinical cases of hyper pigmentation seen in the region (Figure 2).

\subsubsection{Carcinogenic Effects}

Major cancers associated with arsenic exposure are cancers of the skin, bladder, lung, kidney and liver. Table 6 
Table 4. Exposure doses for non-carcinogenic effects with scenario 1.

\begin{tabular}{|c|c|c|c|c|c|c|c|c|}
\hline \multicolumn{9}{|c|}{$\begin{array}{l}\text { Scenario 1: Exposed population: individuals from } 0 \text { to } 14 \text { years } \\
\text { Ed: } 7 \text { years, IR }(\mathrm{kg} / \mathrm{d})=1, \mathrm{BW}(\mathrm{kg})=29 \\
\text { Ed (years })=7, \text { Total Period }(\text { years })=7\end{array}$} \\
\hline \multirow{2}{*}{$\frac{\text { Province }}{\mathrm{C}(\mu \mathrm{g} / \mathrm{L})}$} & \multicolumn{2}{|c|}{ Yatenga } & \multicolumn{2}{|c|}{ Passoré } & \multicolumn{2}{|c|}{ Zondoma } & \multicolumn{2}{|c|}{ Lorom } \\
\hline & 10 & 16 & 10 & 87 & 10 & 15 & 0 & 0 \\
\hline $\operatorname{ED}\left(\mu \mathrm{g} \cdot \mathrm{kg}^{-1} \cdot \mathrm{d}^{-1}\right)$ & 0.35 & 0.55 & 0.35 & 3 & 0.35 & 0.52 & 0 & 0 \\
\hline
\end{tabular}

Table 5. Exposure doses for non-carcinogenic effects with scenario 2.

\begin{tabular}{|c|c|c|c|c|c|c|c|c|}
\hline \multicolumn{9}{|c|}{$\begin{array}{c}\text { Scénario 1: Exposed population: individuals from } 15 \text { to } 65 \text { years } \\
\text { Ed: } 33 \text { years, IR }(\mathrm{kg} / \mathrm{d})=2, \mathrm{BW}(\mathrm{kg})=50, \mathrm{EF}=1, \\
\text { Ed (years) }=7 \text {, Total Period (years) }=33\end{array}$} \\
\hline \multirow{2}{*}{$\begin{array}{l}\text { Province } \\
\mathrm{C}(\mu \mathrm{g} / \mathrm{L})\end{array}$} & \multicolumn{2}{|c|}{ Yatenga } & \multicolumn{2}{|c|}{ Passoré } & \multicolumn{2}{|c|}{ Zondoma } & \multicolumn{2}{|c|}{ Lorom } \\
\hline & 10 & 16 & 10 & 87 & 10 & 15 & 0 & 0 \\
\hline $\operatorname{ED}\left(\mu \mathrm{g} \cdot \mathrm{kg}^{-1} \cdot \mathrm{d}^{-1}\right)$ & 0.4 & 0.64 & 0.4 & 3.48 & 0.4 & 0.6 & 0 & 0 \\
\hline
\end{tabular}

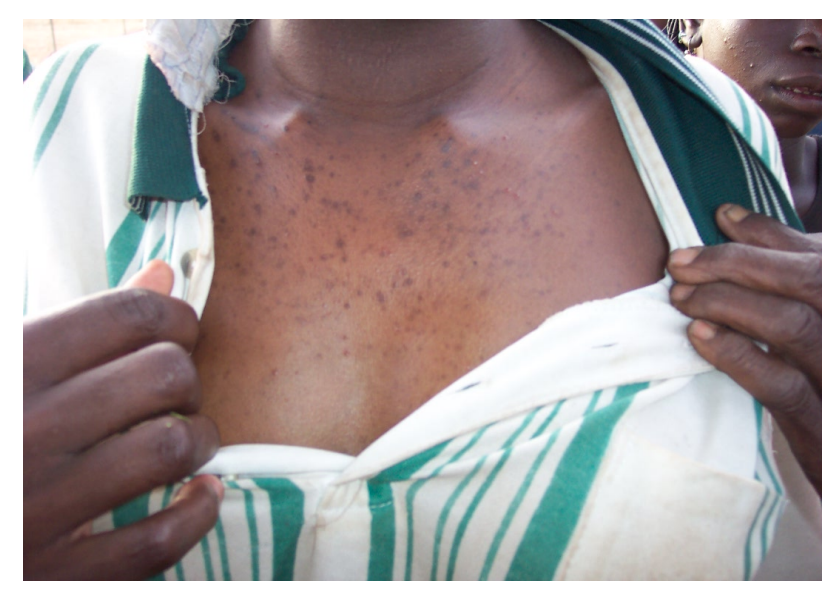

Figure 2. Skin hyper pigmentation.

shows the target exposure and the effects of arsenic on humans in the North region, Burkina Faso.

In summary, chronic exposure to arsenic is known as arsenicosis and there is a significant latency period before symptoms are developed. There appears to be discrepancy in the literature regarding latency, with some reports of 2 years being the minimum for hyper pigmentation and keratosis. Researchers in Bangladesh suggest that 5 years is the minimum latency, whilst some other estimates suggest that this is 9 years. Latency for cancers is also unknown, but it is estimated to be of the order of 20 years [15].

\subsection{Risk Characterization}

For risk characterization, we follow the protocol described by the United States Environmental Protection Agency [16].

Non carcinogenic effects: the potential for non-cancer effects is evaluated by comparing the estimated daily intake of the chemical over a specific time period with the RfD for that chemical derived for a similar period of exposure. This comparison results in a non-carcinogenic Hazard Quotient (HQ), as follows:

$$
\mathrm{HQ}=\mathrm{DI} / \mathrm{RfD}
$$

where:

$$
\begin{aligned}
& \mathrm{HQ}=\text { Hazard Quotient } \\
& \mathrm{DI}=\text { Daily Intake (mg/kg-day) } \\
& \mathrm{RfD} \text { = Reference Dose (mg/kg-day) }
\end{aligned}
$$

with a RfD of $7 \times 10^{-5} \mathrm{mg} \cdot \mathrm{kg}^{-1} \cdot \mathrm{d}^{-1}$, calculated HQ for the North region of Burkina Faso are summarized in Table 7.

In the second scenario, individuals from age 15 to 70 are considered. HQ are summarized in Table 8.

For carcinogenic effects: the excess risk of cancer from exposure to a chemical is described in terms of the probability that an exposed individual will develop cancer because of that exposure by age 70 . For each chemical of concern, this value is calculated from the daily intake of the chemical from the site averaged over a lifetime (DIL) and the slope factor (SF) for the chemical, as follows:

$$
\text { Excess Cancer Risk }=1-\exp (-\mathrm{DIL} \times \mathrm{SF})
$$

In most cases (except when the product of DIL $\times$ SF is larger than about 0.01 ), this equation may be accurately approximated by the following:

$$
\text { Excess Cancer Risk }=\text { DIL } \times \text { SF }
$$

Excess cancer risks are summed across all chemicals of concern and all exposure pathways that contribute to exposure of an individual in a given population. Results from our study (Individual Excess Cancer Risk, quoted IECR) are in Table 9.

The level of total cancer risk that is of concern is a matter of personal, community, and regulatory judgment [14]. In our study, the risk induced by arsenic for noncancer effects is acceptable when HQ is less than $1 \mathrm{E}+$ 00. When children aged $0-14$ are subject to Arsenic concentrations below $87 \mathrm{~g} / \mathrm{L}$ the risk is huge in all cases and HQ $>1$. These concentrations can cause disease to these children. However, concentrations under the norm can induce the same disease when other environmental factors are taken into account. Adults (from 15 years) subject to As pollution have a high risk of getting sick when the arsenic concentration exceeds the standard of 10 $\mu \mathrm{g} / \mathrm{L}$. The risk is increased when other environmental conditions are taken into account.

For carcinogenic effects, the World Health Organization (WHO) gives as limit HQ of $10^{-5}$ [17] which is far below calculated values in our study. Individuals in the region are exposed to arsenic concentrations higher than $10 \mu \mathrm{g} / \mathrm{L}$ and are at very high risk of having cancer because values HQ that we find are more than 60 times the WHO guide. Water containing As values above the guideline 
Table 6. Calculated daily intake in the North region.

\begin{tabular}{|c|c|c|c|c|c|c|c|c|c|c|c|c|}
\hline \multirow{3}{*}{$\begin{array}{l}\text { Province } \\
\mathrm{C}(\mu \mathrm{g} / \mathrm{L})\end{array}$} & \multicolumn{12}{|c|}{$\mathrm{Ed}=33, \mathrm{Q}(\mathrm{kg} / \mathrm{d})=2, \mathrm{BW}=65 \mathrm{~kg}, \mathrm{TE}=1$, Total Period $=52$} \\
\hline & \multicolumn{3}{|c|}{ Yatenga } & \multicolumn{3}{|c|}{ Passoré } & \multicolumn{3}{|c|}{ Zondoma } & \multicolumn{3}{|c|}{ Loroum } \\
\hline & 5 & 10 & 16 & 5 & 10 & 86 & 5 & 10 & 16 & 5 & 5 & 5 \\
\hline
\end{tabular}

Table 7. Hazard Quotient (HQ) for non-carcinogenic effects in Scenario 1.

\begin{tabular}{|c|c|c|c|c|c|c|c|c|}
\hline \multicolumn{9}{|c|}{ Scénario $1 \mathrm{HQ}=\mathrm{DI} / \mathrm{RfD} ;$ Acceptable risk if $\mathrm{HQ}<1$} \\
\hline \multicolumn{9}{|c|}{ Population now exposed, individuals from 0 to 14 years, RfD $\left(\mathrm{VTR}=7 \times 10^{-5} \mathrm{mg} \cdot \mathrm{kg}^{-1} \cdot \mathrm{d}^{-1}\right)$} \\
\hline & \multicolumn{2}{|c|}{ Yatenga } & \multicolumn{2}{|c|}{ Passore } & \multicolumn{2}{|c|}{ Zondoma } & \multicolumn{2}{|c|}{ Loroum } \\
\hline Hazard quotient (HQ) & 4.92 & 7.88 & 4.92 & 42.85 & 4.92 & 7.38 & 0 & 0 \\
\hline
\end{tabular}

Table 8. Hazard Quotient (HQ) for non-carcinogenic effects in Scenario 2.

\begin{tabular}{|c|c|c|c|c|c|c|c|c|}
\hline \multicolumn{9}{|c|}{ Scénario $1 \mathrm{HQ}=\mathrm{DI} / \mathrm{RfD} ;$ Acceptable risk if $\mathrm{HQ}<1$} \\
\hline \multicolumn{9}{|c|}{ Population now exposed, individuals from 15 to 70 years, $R f D\left(V T R=7 \times 10^{-5} \mathrm{mg} \cdot \mathrm{kg}^{-1} \cdot \mathrm{d}^{-1}\right)$} \\
\hline & \multicolumn{2}{|c|}{ Yatenga } & \multicolumn{2}{|c|}{ Passore } & \multicolumn{2}{|c|}{ Zondoma } & \multicolumn{2}{|c|}{ Loroum } \\
\hline $\mathrm{DI}\left(\mu \mathrm{g} \cdot \mathrm{kg}^{-1} \cdot \mathrm{d}^{-1}\right)$ & 0.34 & 0.55 & 0.34 & 3 & 0.34 & 0.51 & 0 & 0 \\
\hline Hazard quatient (HQ) & 5.71 & 9.14 & 5.71 & 49.71 & 5.71 & 8.51 & 0 & 0 \\
\hline
\end{tabular}

Table 9. Calculated Individual Excess Cancer Risk (IECR) and Collective Excess Cancer Risk (CECR).

\begin{tabular}{|c|c|c|c|c|c|c|c|c|c|c|c|c|}
\hline \multirow[b]{2}{*}{ Province } & \multicolumn{12}{|c|}{$\begin{array}{l}\text { Scenario 1: Individuals from } 15 \text { to } 70 \text { years } \\
\text { Unitary Excess Risk }(\mathrm{UER}=1.5), \mathrm{IECR}=\mathrm{DI} \times \mathrm{UER}, \mathrm{CECR}=\mathrm{UICR} \times \text { exposed population }\end{array}$} \\
\hline & \multicolumn{3}{|c|}{ Yatenga } & \multicolumn{3}{|c|}{ Passoré } & \multicolumn{3}{|c|}{ Zondoma } & \multicolumn{3}{|c|}{ Loroum } \\
\hline $\mathrm{ED}\left(\mu \mathrm{g} \cdot \mathrm{kg}^{-1} \cdot \mathrm{d}^{-1}\right)$ & 0.0976 & 0.195 & 0.312 & 0.0976 & 0.195 & 1.68 & 0.9976 & 0.195 & 0.312 & 0.0976 & 0.0976 & 0.0976 \\
\hline $\operatorname{IECR}\left(\times 10^{-4}\right)$ & 1.46 & 2.93 & 4.69 & 1.46 & 2.93 & 25.2 & 1.46 & 2.93 & 4.69 & 1.46 & 1.46 & 1.46 \\
\hline CECR & 67 & 133 & 213 & 39 & 78 & 345 & 20 & 40 & 55 & 17 & 17 & 17 \\
\hline
\end{tabular}

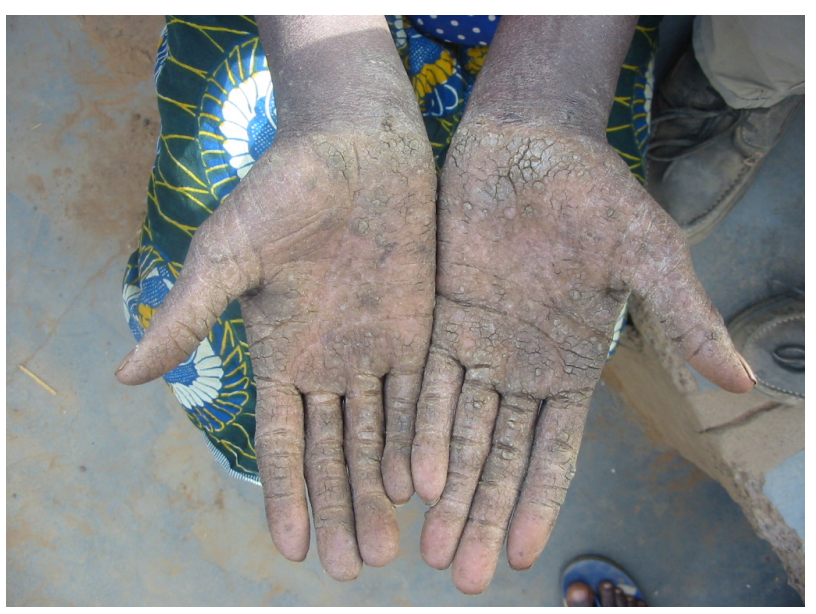

Figure 3. Palmar keratosis (skin cancer).

value should therefore be subjected to prior treatment. Affordable technologies are available [18]. When this treatment is not possible these water points should be prohibited for human consumption until treatment is found.

The following photos illustrate reported clinical cases of non carcinogenic (Figure 2) and carcinogenic (Figure 3) risks to which people are exposed in the North region.

\section{Conclusions}

The delayed effects on health of exposure to arsenic, the lack of common definitions, the lack of local awareness and the poor reporting in affected areas are the main obstacles that stumble determining the magnitude of the problem of arsenic in drinking water in Burkina Faso. Clinical cases of cancers associated with arsenic in drinking water were reported in the provinces of Passoré, Zondoma and Yatenga. This study allowed us to assess the extent of problems related to arsenic in groundwater. Pollution of groundwater caused the health risk and death in the North region.

Under the light of the results this study, it seems clear that measures should be taken at various levels to try to address the risks associated with water contamination by arsenic. Firstly appropriate technologies for arsenic removal from drinking water should be considered and secondly public targeted information should be developed in order to confront arsenic with appropriate tech- 
nologies rather than fly it by closing water points.

\section{REFERENCES}

[1] Ministry of Agriculture and Water Resources, "2011 Statistical Yearbook of Drinking Water and Wastewater and Excreta," 2011, pp. 35-40.

http://cns.bf/IMG/pdf/meaha_annuairestatistiqueaepa_20 11_vf-2.pdf

[2] Water and Environment Program of the North, "Realization of 360 Drillings in Villages of the Provinces of Yatenga, Lorum, Passoré and Zondoma from 1994 to 2004," Arsenic Poisoning in the North: Two Dead and Eleven Wells Embargoed. http://www.lefaso.net/spip.php?article18173

[3] P. L. Smedley, J. Knudsen and D. Maiga, "Arsenic in Groundwater from Mineralised Proterozoic Basement Rocks of Burkina Faso," Applied Geochemistry, Vol. 22, No. 5, 2007, pp. 1074-1092. doi:10.1016/j.apgeochem.2007.01.001

[4] I. T. Somé, A. K. Sakira, M. Ouédraogo, T. Z. Ouédraogo, A. Traoré, B. Sondo and P. I. Guissou, "Arsenic Levels in Tube-Wells Water, Food, Residents' Urine and the Prevalence of Skin Lesions in Yatenga Province, Burkina Baso," Interdisciplinary Toxicology, Vol. 5, No. 1, 2012, pp. $38-41$.

http://www.ncbi.nlm.nih.gov/pmc/articles/PMC3389508

[5] Institut Géographique du Burkina, "Cartoweb-Region Nord," 2012. http://www.igb.bf/pagehtm/carteweb.htm

[6] S. Nakolendousse, "Méthode d'Evaluation de la Productivité des Sites Aquifères au Burkina Faso," Ph.D. Thesis, Université Joseph Fourier, Grenoble, 1991.

[7] P. L. Smedley and D. G. Kinniburgh, "A Review of the Source, Behaviour and Distribution of Arsenic in Natural Waters," Applied Geochemistry, Vol. 17, No. 5, 2002 pp. 517-568.

[8] D. van Halem, S. A. Bakker, G. L. Amy and J. C. van Dijk, "Arsenic in Drinking Water: A Worldwide Water Quality Concern for Water Supply Companies," Drinking Water Engineering Science, Vol. 2, No. 1, 2009, pp. 2934.

http://www.drink-water-eng-sci.net/2/29/2009/dwes-2-29 $-2009 . p d f$
[9] M. Rahman, V. M. Sohel, M. Yunus, M. A. Wahed and P. K. Stretfrield, "Arsenic Exposure and Age-Sex Specific Risk for Skin Lesions: A Population Based Case-Referent Study in Bangladesh," Environ Health Perspect, Vol. 114, No. 12, 2006, pp. 1847-1852.

[10] INERIS, “Choix des Valeurs Toxicologiquesde Référence (VTR)-Arsenic," 2006. http://www.ineris.fr/centredoc/06DR082_rapport_final.p df

[11] W. P. Tseng, H. M. Chu, S. W. How, J. M. Fong, C. S. Lin and S. Yeh, "Prevalence of Skin Cancer in an Endemic Area of Chronic Arsenicism in Taiwan," Journal of the National Cancer Institute, Vol. 40, No. 3, 1968, pp. 453-463.

[12] W. P. Tseng, "Effects and Dose-Response Relationships of Skin Cancer and Blackfoot Disease with Arsenic," Environmental Health Perspectives, Vol. 19, 1977, pp 109119. doi:10.1289/ehp. 7719109

[13] Institut National de la Statistique et de la Démographie, "Résultats Définitifs du Recensement Général de la Population et de l'Habitat 2006," 2009. http://cns.bf/IMG/pdf/population_1997-2006.pdf

[14] Agency for Toxic Substances \& Disease Registry, "Public Health Assessment Guidance Manual. Appendix G: Calculating Exposure Doses," 2005. http://www.atsdr.cdc.gov/hac/phamanual/appg.html

[15] World Health Organization, “Arsenic, Drinking-Water and Health Risk Substitution in Arsenic Mitigation: A Discussion Paper," 2012.

http://www.who.int/water_sanitation_health/dwq/wsh030 6/en/index 2.html

[16] United States Environmental Protection Agency, "Risk Characterization," 2013. http://www.epa.gov/region8/r8risk/hh_risk.html

[17] World Health Organization, "Drinking Water Guidelines and Standards," 2013.

http://www.who.int/water_sanitation_health/dwq/arsenicu n5.pdf

[18] N. R. Khandaker, P. V. Brady and J. L. Krumhansl, “Arsenic Removal from Drinking Water: A Handbook for Communities,"

http://www.sandia.gov/water/docs/NRK_PVB_JLK_As_ Book.pdf 